\title{
Synthesis and characterization of nickel oxide doped barium strontium titanate ceramics
}

\section{(Síntese e caracterização de cerâmicas de titanato de estrôncio e bário dopado com óxido de níquel)}

\author{
M. Banerjee ${ }^{1}$, S. Mukherjee ${ }^{2}$, S. Maitra ${ }^{3}$ \\ ${ }^{1}$ Dept. of Electrical Engineering, Bengal Institute of Technology Kolkata, India \\ ${ }^{2}$ Dept. of Metallurgical Engineering, Jadavpur University, Kolkata, India \\ ${ }^{1}$ Govt. College of Engg. \& Ceramic Technology, Kolkata, India
}

\begin{abstract}
Barium strontium titanate (BST) ceramics $\left(\mathrm{Ba}_{0.6} \mathrm{Sr}_{0.4}\right) \mathrm{TiO}_{3}$ were synthesized by solid state sintering using barium carbonate, strontium carbonate and rutile as the precursor materials. The samples were doped with nickel oxide in different proportions. Different phases present in the sintered samples were determined from X-ray diffraction investigation and the distribution of different phases in the microstructure was assessed from scanning electron microscopy study. It was observed that the dielectric properties of BST were modified significantly with nickel oxide doping. These ceramics held promise for applications in tuned circuits.
\end{abstract}

Keywords: barium strontium titanate, solid state reactions, nickel oxide doping, dielectric properties, microstructure.

\section{Resumo}

Cerâmicas de titanato de bário e estrôncio (TBS) $\left(\mathrm{Ba}_{0,6} \mathrm{Sr}_{0,4}\right) \mathrm{TiO}_{3}$ foram sintetizadas por sinterização do estado sólido usando carbonato de bário, carbonato de estrôncio e rutilo como materiais precursores. As amostras foram dopadas com diferentes proporções de óxido de níquel. Diferentes fases presentes nas amostras sinterizadas foram determinadas por difração de raios $X$ e a distribuição de diferentes fases na microestrutura foi avaliada por microscopia eletrônica de varredura. Foi observado que as propriedades dielétricas do TBS foram modificadas significativamente com a dopagem do óxido de níquel. Essas cerâmicas são promissoras para aplicação em dispositivos.

Palavras-chave: titanato de bário e estrôncio, reação no estado sólido, dopagem com óxido de níquel, propriedades dielétricas, microestrutura.

\section{INTRODUCTION}

Conventionally ferrites are used phase shifter in microwave-tuned circuits for the construction of phased array antennas. But these materials are costly and devices made from them are bulky. Therefore for the purpose of miniaturization as well as for making light weight devices with improved features a better dielectric material is needed. The material should be associated with relatively lower value of dielectric constant to minimize the overall impedance mismatch. Again to lower the insertion loss a low value of loss factor is also required for these materials.

Barium-strontium titanate (BST) is a ternary ceramic compound with the stoichiometric formula $\left(\mathrm{Ba}_{\mathrm{x}} \mathrm{Sr}_{1-\mathrm{x}}\right)$ $\mathrm{TiO}_{3}$. It satisfies the different requirement for phasearray applications, which include relatively low dielectric constant, low dielectric loss and high dielectric tunability in the frequency range from $1 \mathrm{kHz}$ to $1 \mathrm{MHz}[1,2]$. The microwave-tuned circuits can be designed using field or voltage controlled BST ferroelectric materials. Many researches have preferred BST ceramics for its use in high performance microwave tunable devices, such as phase shifter, tunable filters, steerable antennas etc [3-5].

For the synthesis of BST ceramics, barium titanate and strontium titanate phases can be mixed intimately to develop a homogeneous phase composition [6,7]. The Curie temperature $\left(\mathrm{T}_{\mathrm{C}}\right)$ of BST can be changed by adjusting the $\mathrm{Ba}: \mathrm{Sr}$ ratio $[8,9]$.

The dielectric properties of BST are dependent on the composition, nature and amount of doping. It has been observed that a linear relationship between the Curie temperature of the $\left(\mathrm{Ba}_{\mathrm{x}} \mathrm{Sr}_{1-\mathrm{x}}\right) \mathrm{TiO}_{3}$ material and the fraction of strontium (x) exists for $\mathrm{x} \leq 0.75$ [10]. The real part of the dielectric constant for $\left(\mathrm{Ba}_{\mathrm{x}} \mathrm{Sr}_{1-\mathrm{x}}\right) \mathrm{TiO}_{3}$ varies over a range of 200-900 and the loss factor of $\left(\mathrm{Ba}_{x} \mathrm{Sr}_{1-x}\right) \mathrm{TiO}_{3}$ ceramics varies over a range of $\tan \delta=10^{-3}-10^{-2}$, at a frequency of $\sim 2 \mathrm{GHz}$ [11]. As the dielectric loss is usually lower in the paraelectric state than in the ferroelectric state owing to the disappearance of hysteresis, BST at paraelectric phase shows a lower loss tangent value than ferroelectric 
phase. There have been many studies on the development of the dielectric properties of BST materials at paraelectric phase. However, the high dielectric loss, especially in the microwave frequency range, limits its further development. To overcome this limitation, it is very important to study the dielectric characteristics and loss tangent at different frequencies. It is well known that the dielectric properties of BST at paraelectric phase can be further modified using dopants of various concentrations.

In the above context, the microstructure, dielectric property and loss tangent ( $\tan \delta$ ) of the nickel oxide doped BST (for $\mathrm{x}=0.6$ ) samples at different frequencies and temperature ranges was studied in the present work. The effect of different degrees of $\mathrm{Ni}$ doping was studied in order to explore the applications of the materials for high performance microwave tunable devices.

\section{EXPERIMENTAL}

\section{Sample preparation}

$\left(\mathrm{Ba}_{0.6} \mathrm{Sr}_{0.4}\right) \mathrm{TiO}_{3}$ was prepared with various concentrations [1.0, 0.5 and 0.25 wt.\%] of $\mathrm{NiO}$ dopant by traditional ceramic processing. The starting materials selected were $\mathrm{BaCO}_{3}, \mathrm{SrCO}_{3}, \mathrm{TiO}_{2}$ and $\mathrm{NiO}$ in powder form and all the materials were taken in the form of analytical grade. The materials were weighed according to the stoichiometric proportions and mixed thoroughly in aqueous phases for homogenization of the compositions. After mixing the aqueous suspension was dried and the dried powders were then calcined under ambient condition at $900{ }^{\circ} \mathrm{C}$ for $2 \mathrm{~h}$ in re-crystallized alumina crucibles. The dry calcined powder was compacted in the form of cylindrical pellets using PVA binder with a compaction pressure of $600 \mathrm{~kg} / \mathrm{cm}^{2}$. The compacts were sintered at $1400{ }^{\circ} \mathrm{C}$ with a soaking period of $2 \mathrm{~h}$ in an electrically heated muffle furnace. These sintered pallets were used for morphological, structural and electrical characterizations.

\section{Characterization}

XRD analysis of the sintered samples was carried out with $\mathrm{X}$-ray diffractometer (Rigaku, Ultima-III, Japan) with Cuk $\alpha$ radiation. SEM photomicrographs of the samples were taken with Leo Cambridge microscope. Dielectric measurements were made in the frequency range $100 \mathrm{~Hz}$ to $20 \mathrm{kHz}$ using the LCZ meter 4276A (Agilent). Sintered samples were ground, polished and cleaned and then heated at $140{ }^{\circ} \mathrm{C}$ for $4 \mathrm{~h}$ in a hot air oven order to eliminate water. The dried samples were coated with silver paste and then reheated at $400{ }^{\circ} \mathrm{C}$ for $1 \mathrm{~h}$. The dielectric constant of each sample was calculated from the measured capacitance and the specimen geometry. The dielectric loss was also measured directly from the instrument reading. For the undoped sample and a sample with $0.25 \%$ $\mathrm{NiO}$ content, the dielectric measurements were carried out from $1 \mathrm{kHz}$ to $1 \mathrm{MHz}$ range as a function of temperature (from $-50{ }^{\circ} \mathrm{C}$ to $+70{ }^{\circ} \mathrm{C}$ ).

\section{RESULTS AND DISCUSSION}

$\mathrm{Ba}_{0.6} \mathrm{Sr}_{0.4} \mathrm{TiO}_{3}$ was chosen as the basic composition because of its good combination of low $\mathrm{T}_{\mathrm{C}}$, high dielectric constant, relatively low loss tangent and good tenability [12]. By adding $40 \mathrm{~mol}_{\%} \mathrm{SrTiO}_{3}$ to $\mathrm{BaTiO}_{3}$, the Curie temperature can be shifted from $120{ }^{\circ} \mathrm{C}$ to $-5{ }^{\circ} \mathrm{C}$, but a relatively high dielectric constant can be maintained above $\mathrm{T}_{\mathrm{C}}$. Heywang [13] developed a model for the positive temperature coefficient effect above $T_{C}$. In this model the presence of two dimensional layers of surface acceptor states, either oxygen or the acceptor ions, is assumed at the grain boundaries of $\mathrm{BaTiO}_{3}$. The acceptors act as traps, taking electrons from the interiors of the grains. This results in a potential barrier at the grain boundary. As the temperature is increased above $T_{C}$ with the decrease in permittivity, the trapped electrons gain enough energy to jump to the conduction band. Therefore the conductivity increases with temperature.

In this study, the composition of the material was adjusted in order to get the dopant substitution on $\mathrm{B}$ sites of perovskite $\mathrm{ABO}_{3}$ structure. The starting powders were mixed to get $\mathrm{Ba}_{0.6} \mathrm{Sr}_{0.4} \mathrm{Fe}_{\mathrm{x}} \mathrm{Ti}_{1-\mathrm{x}} \mathrm{O}_{3}$ with an $\mathrm{A}$ : $\mathrm{B}$ ratio of 1:1. It was assumed that all of the dopants occupied $\mathrm{B}$ sites. For capacitor ceramics $\mathrm{ABO}_{3}$, doping with acceptor ions in small amounts on B sites can significantly influence the dielectric properties [14-16]. In $\mathrm{NiO}$ some proportions $\mathrm{Ni}^{3+}$ cations (in the form of $\mathrm{Ni}_{2} \mathrm{O}_{3}$ ) exist and this cation can be considered as acceptor dopant as it has a lower valency than $\mathrm{Ti}^{4+}$. The substitution of $\mathrm{Ti}^{4+}$ by $\mathrm{Ni}^{3+}$ would give rise to a vacancy in the oxygen sub-lattice as per the following reactions:

$$
\begin{aligned}
& \mathrm{Ni}_{2} \mathrm{O}_{3}+2(\mathrm{BaO} \cdot \mathrm{SrO}) \rightarrow 2(\mathrm{Ba} \cdot \mathrm{Sr})+2 \mathrm{Ni}^{\prime}{ }_{\mathrm{B}}++5 \mathrm{O}_{\mathrm{o}}+\mathrm{V}_{\mathrm{o}} \\
& \mathrm{NiO}+(\mathrm{BaO} \cdot \mathrm{SrO}) \rightarrow(\mathrm{Ba} \cdot \mathrm{Sr})+\mathrm{Ni}^{\prime \prime}{ }_{\mathrm{B}}+2 \mathrm{O}_{\mathrm{o}}+\mathrm{V}_{\mathrm{o}}
\end{aligned}
$$

The final electroneutrality is maintained with the following stoichiometry:

$$
(\mathrm{Ba} . \mathrm{Sr})\left(\mathrm{Ni}_{\mathrm{Ti}}^{\prime}\right)_{\mathrm{x}} \mathrm{Ti}_{1-\mathrm{x}}\left(\mathrm{V}_{{ }_{0}}\right)_{\mathrm{x} / 2} \mathrm{O}_{3-\mathrm{x} / 2} \text { and }(\mathrm{Ba} \cdot \mathrm{Sr})\left(\mathrm{Ni}^{\prime \prime}{ }_{\mathrm{Ti}}\right)_{\mathrm{x}} \mathrm{Ti}_{1-\mathrm{x}}\left(\mathrm{V}_{{ }_{0}}\right)_{\mathrm{x}} \mathrm{O}_{3-\mathrm{x}}
$$

The cationic size of $\mathrm{Ni}^{2+}$ is $0.83 \AA$ and of $\mathrm{Ni}^{3+}$ is $0.72 \AA$ compared to $\mathrm{Ti}^{4+}(0.61 \AA)$. Therefore this substitution causes expansion in the $\mathrm{ABO}_{3}$ structure and modifies the dielectric properties. Donor dopants generally occupy A

Table I - Ionic radii $(\AA)$ [11].

[Tabela I - Raios iônicos $(\AA)$ [11].]

\begin{tabular}{ccc}
\hline & $\begin{array}{c}\text { 6-fold } \\
\text { coordination }\end{array}$ & $\begin{array}{c}\text { 12-fold } \\
\text { coordination }\end{array}$ \\
\hline $\mathrm{A}$-site ions & & \\
$\mathrm{Ba}^{2+}$ & 1.36 & 1.44 \\
$\mathrm{Sr}^{2+}$ & 1.16 & 1.60 \\
$\mathrm{Ni}^{2+}$ & 0.81 & \\
$\mathrm{~B}-$ site ions $^{2+}$ & & \\
$\mathrm{Ti}^{4+}$ & 0.61 & \\
$\mathrm{Ni}^{3+}$ & 0.72 & \\
\hline
\end{tabular}


sites and acceptor dopant generally occupy B sites. The issue of dopants acting as donor or acceptors on A or B sites respectively is debatable. Some researchers suggest that $2+$ or $3+$ ions occupy A sites as donors compensated by A site vacancies of $\mathrm{Ti}^{4+}$ ions, while others suggest that the ions occupy B sites as acceptors. From a comparison of the ionic radii of the various cations, it is reasonable to assume a substitution of $\mathrm{Fe}^{3+}$ on $\mathrm{Ti}^{4+}$ sites (Table I).

While phase shifting ceramics are essentially capacitors and are tested as such, they are used at generally higher frequencies than capacitors. Also a low loss tangent and the ability to achieve a larger $\Delta \varepsilon$ with applied bias voltage become important properties in phase shifting devices and these properties are further examined here for the addition of the dopants.

All compositions showed a density after sintering of approximately larger than $90 \%$ of the theoretical density. After sintering, the powder density of all of the sintered masses was approximately $5 \mathrm{~g} / \mathrm{cm}^{3}$, which is about $90 \%$ of the theoretical density.

In the present investigation the dopant $\mathrm{NiO}$ served two purposes. It modifies the dielectric properties by substitution at the $\mathrm{Ti}^{4+}$ sites and at the same time it promoted sintering of the compacts with the formation of vacancies in the cationic site. Again, after sintering, the excess nickel oxide at the grain boundaries further may develop conducting phases at the grain boundaries and can affect the capacitance and dielectric loss values of the materials. With the increase in the $\mathrm{NiO}$ content the dielectric constant of BST decreased (Fig. 1), due to the development of a conducting phase in the microstructure. For the undoped material after $1 \mathrm{kHz}$ frequency the dielectric constant values were observed to be decreased significant only at frequencies below $10 \mathrm{kHz}$. At higher frequencies and with the higher proportion of $\mathrm{NiO}$ content the change in dielectric constant was not significant.

Dissipation factor or $\tan \delta$ is a measure of loss-rate of power of a mechanical mode, such as oscillation in a

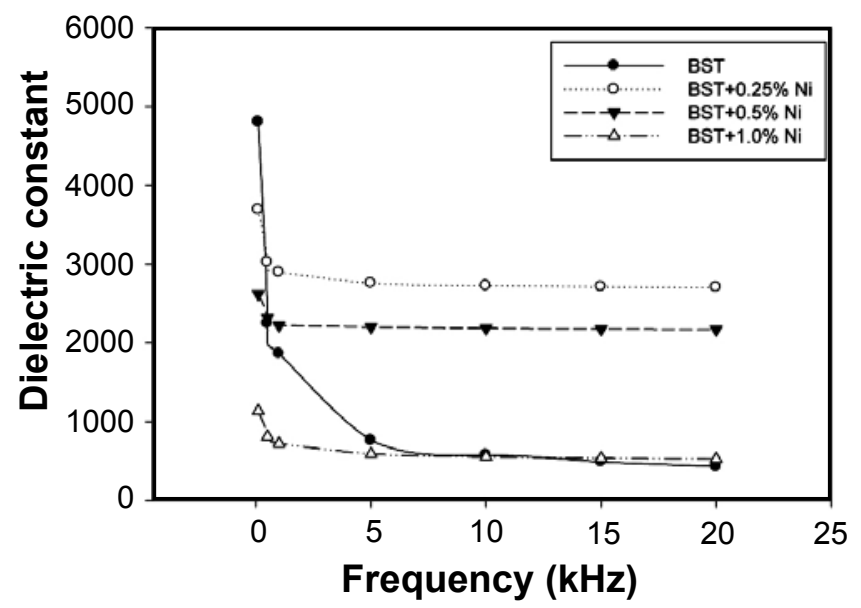

Figure 1: Variation in dielectric constant with frequency for $\mathrm{Ni}$ doped BST.

[Figura 1: Variação da constante dielétrica com a freqüência do BST dopado com Ni.] dissipative system. It is expressed as the ratio of the resistive power loss to capacitive power loss. With the increase in the $\mathrm{NiO}$ content the loss tangent values also decreased (Fig. 2). It can be related to the development of a more conducting phase in the microstructure which reduced the resistive power loss of the materials. With the increase in the frequency, the loss factor decreased for all the compositions.

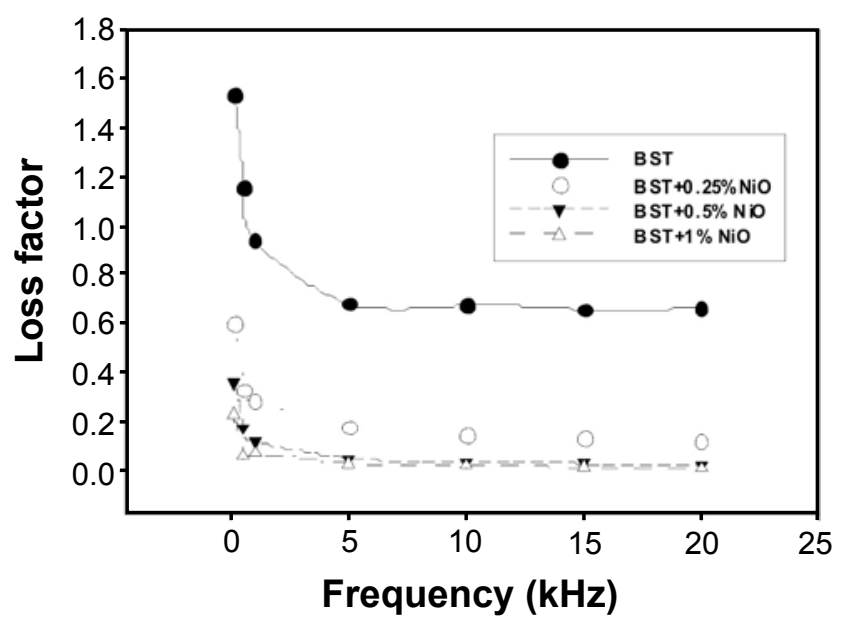

Figure 2: Variation in loss factor with frequency for Ni-doped BST. [Figura 2: Variação do fator de perda com a freqüência do BST dopado com $\mathrm{Ni}$.]

To compare the performance of the doped material with respect to the undoped material, a composition with $0.25 \%$ $\mathrm{NiO}$ content was chosen. The dielectric constant values of the $\mathrm{NiO}$-doped sample were always lower at all temperatures under investigation. The NiO-doped material exhibited a diffused small peak in the dielectric constant of $\sim 5000$ at the $\mathrm{T}_{\mathrm{c}}$ of $-10{ }^{\circ} \mathrm{C}$ (Fig. 3). The undoped material had a much sharper peak in the dielectric constant of $\sim 9000$ at the $\mathrm{T}_{\mathrm{c}}$ of -5 ${ }^{\circ} \mathrm{C}$. The lowering of the dielectric constant and the diffused character of the maxima can be related to the presence of conducting grain boundary and ion vacancy in the samples. With the increase in the temperature, the dielectric constant

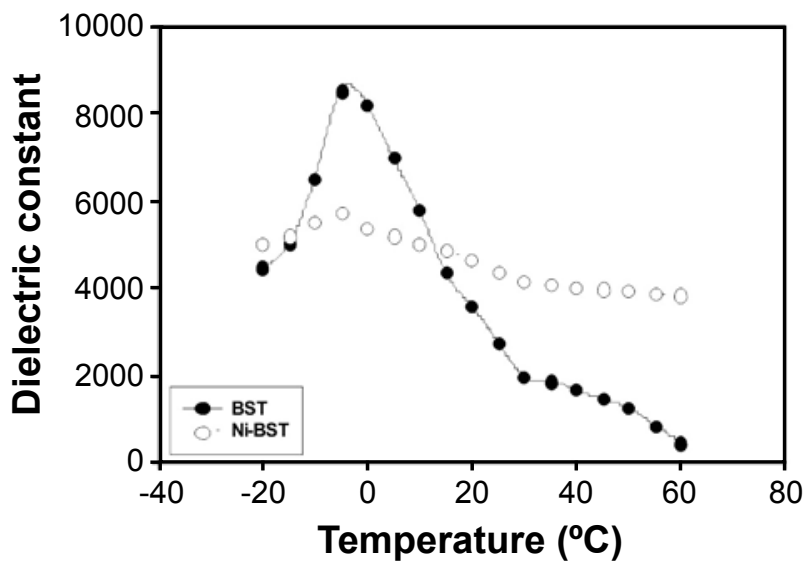

Figure 3: Variation dielectric constant with temperature for $\mathrm{Ni}$ BST.

[Figura 3: Variação da constante dielétrica com a temperatura para Ni-BST.] 
of the undoped samples decreased significantly, but for the doped sample the change in dielectric constant with

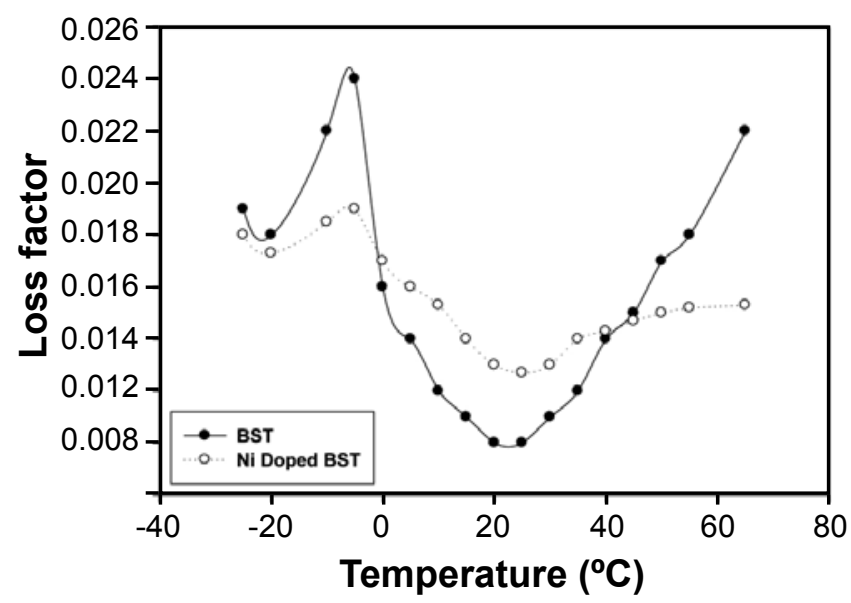

Figure 4: Variation in loss factor with temperature for Ni-BST.

[Figura 4: Variação do fator de perda com a temperatura para Ni-BST.]

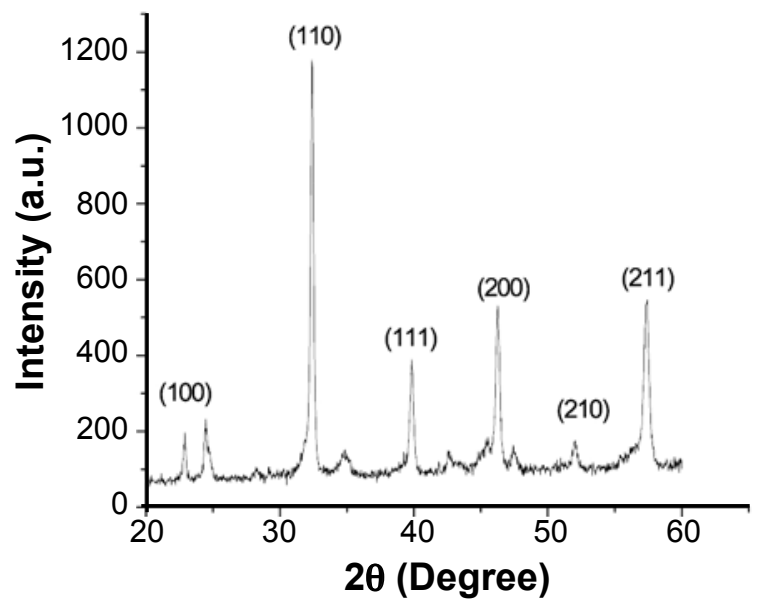

Figure 5: (A) XRD diffraction pattern of the BST sample. [Figura 5: (A) Difratograma de raios X da amostra BST.]

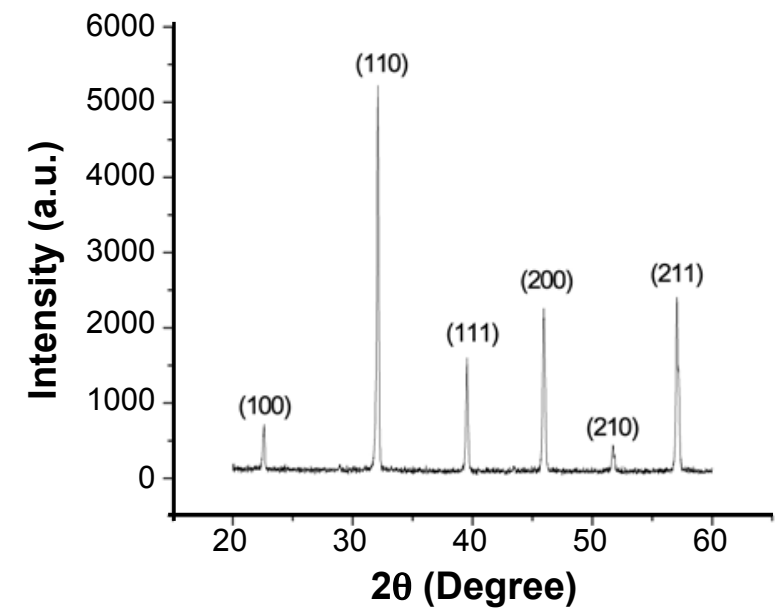

Figure 5: (C) XRD diffraction pattern of the BST with $0.5 \% \mathrm{NiO}$. [Figura 5: (C) Difratograma de raios $X$ da amostra BST com 0,5\% $\mathrm{NiO}$.] temperature was not significant. The loss tangent value of the doped sample was higher compared to the undoped sample at very low temperature (Fig. 4). But with the increase in temperature, the loss tangent value of the doped samples became less compared to the undoped sample up to $40{ }^{\circ} \mathrm{C}$. It implies that at this temperature range the resistive power loss becomes more important for the doped sample.

In general, the dielectric constant and loss factor of Nidoped BST maintained almost a steady value over a range of lower frequencies. The change in dielectric constant and loss factor with temperature for the Ni-doped BST is not significant compared to the un-doped BST. The loss tangent increased greatly with lower frequency.

In the XRD pattern of the samples presence of BST phases were identified (Figs. 5A-5D). The crystal structure is basically cubic. The phase compositions of the samples did not change with $\mathrm{NiO}$ content, indicating that the dopant did not develop other undesirable phases in the microstructure. But the relative intensity of the phases improved significantly with the addition of the dopants. It indicates that $\mathrm{NiO}$ played

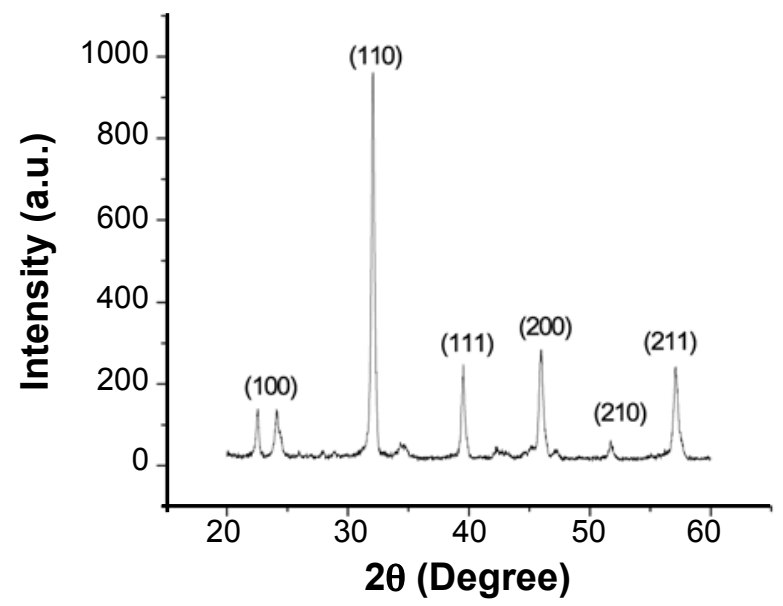

Figure 5: (B) XRD diffraction pattern of the BST with $1 \% \mathrm{NiO}$. [Figura 5: (B) Difratograma de raios X da amostra BST com $1 \%$ NiO.]

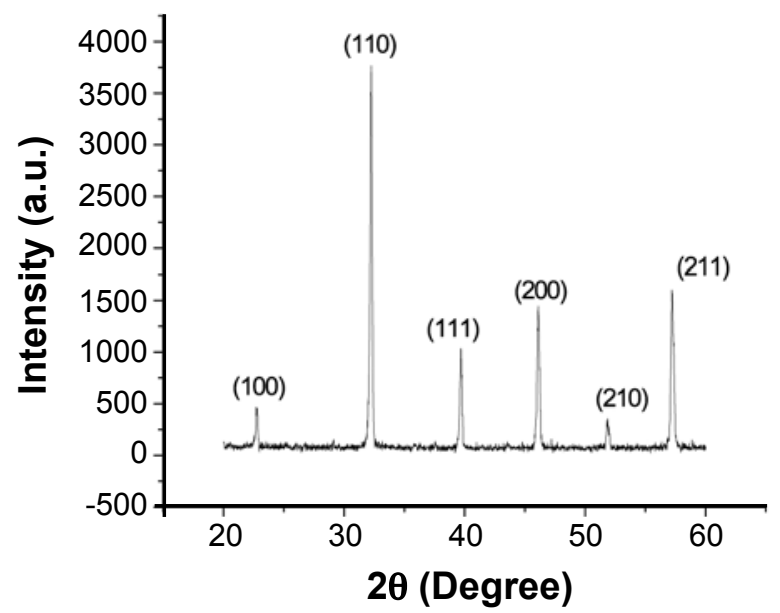

Figure 5: (D) XRD diffraction pattern of the BST with $0.25 \% \mathrm{NiO}$. [Figura 5: (D) Difratograma de raios $X$ da amostra BST com $0,25 \% \mathrm{NiO}$.] 
a positive role in sintering and crystallization of BST. The crystal structure and cell dimension was not altered with the addition of the dopant. The average grain sizes of the samples decreased with the increase in the $\mathrm{NiO}$ content (Table II). It can be related with the grain boundary blocking effect of $\mathrm{NiO}$ during the coarsening of the grains at the later stage of sintering in the BST microstructure.

Table II - Average grain size of the samples. [Tabela II - Tamanho médio de grãos das amostas.]

\begin{tabular}{cc}
\hline Sample & Average Grain Size $(\mu \mathrm{m})$ \\
\hline BST & 8.17 \\
BST $+0.25 \%$ Nickel & 7.19 \\
oxide & 6.03 \\
BST $+0.5 \%$ Nickel Oxide & 5.14 \\
BST $+1 \%$ Nickel Oxide & \\
\hline
\end{tabular}
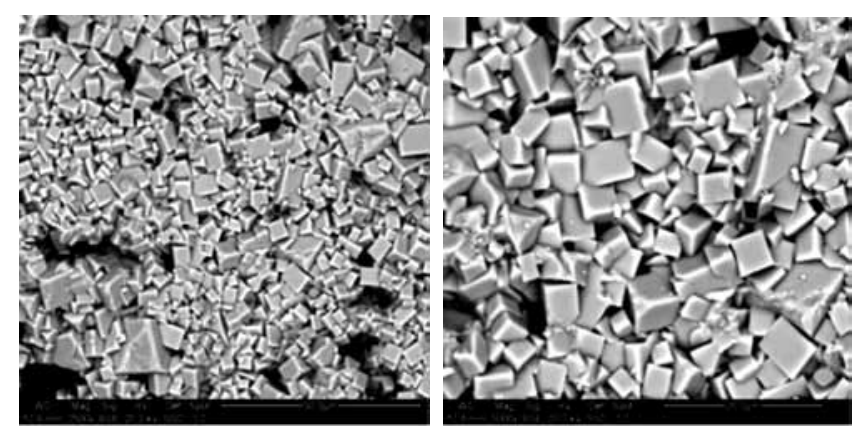

Figure 6: (A) SEM photograph of BST with $1 \% \mathrm{NiO}$.

[Figura 6: (A) Micrografia obtida por MEV de BST com $1 \%$ NiO.]
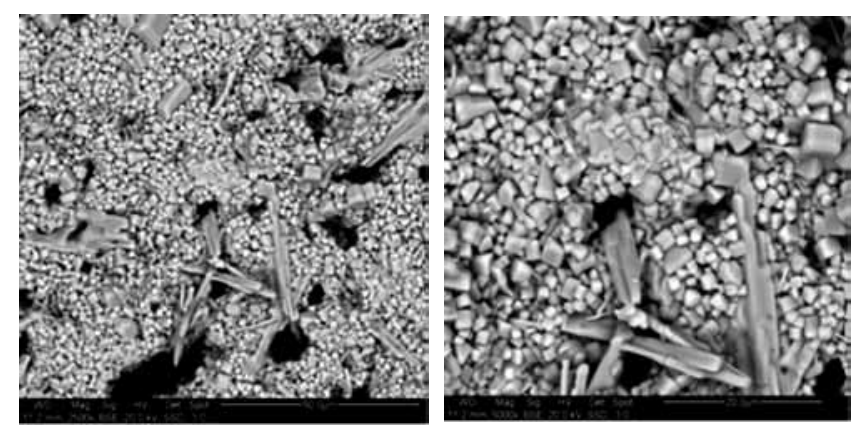

Figure 6: (B) SEM photograph of BST with $0.5 \% \mathrm{NiO}$.

[Figura 6: (B) Micrografia obtida por MEV de BST com 0,5\% NiO.]
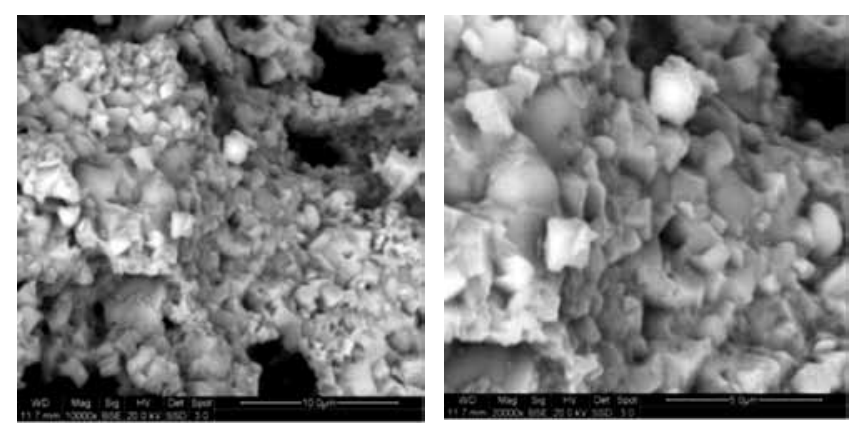

Figure 6: (C) SEM photograph of BST with $0.25 \% \mathrm{NiO}$.

[Figura 6: (C) Micrografia obtida por MEV de BST com 0,25\% NiO.]
The microstructure of the materials showed the presence of rounded grains, typical of liquid phase sintering (Figs. 6A-6C). With the increase in the addition of the dopants, the grain size decreased. The microstructure became more refined and uniform with the increase in the dopant concentration. No substantial amount of amorphous phase was seen at the grain boundaries in the SEM micrograph. Energy dispersive analysis of X-rays (EDAX) was inconclusive because of the overlap of the $\mathrm{Ba}$ and Ti lines as well as those of the $\mathrm{Fe}$ and background radiation caused by the chamber wall. With Ni doping the loss tangent showed significant reduction. From the Backscattered analysis no substantial difference in brightness was observed in different areas of the microstructure which is indicative of an overall compositional homogeneity throughout the sample.

\section{CONCLUSION}

The role of nickel oxide dopant on the dielectric behavior of BST ceramics was investigated. With the addition of the dopant at the lower frequency (i.e. at near zero frequency), the dielectric constant and loss tangent values of the material decreased significantly compared to the undoped material. The maxima in the dielectric constant and loss factor values became much less and more diffused. The maxima slightly shifted to lower temperatures compared to the undoped sample. The average grain size of the BST ceramics decreased with the increase of the dopant concentration and the microstructure became uniform. These materials held promise for applications in areas where relatively low but stable value of dielectric constant is required without significant power loss, like electrical properties measuring instruments.

\section{REFERENCES}

[1] L. Wu, Y. C. Chen, L. J. Chen, I. Ping Chou, Y. T. Tsai, Jap. J. Appl. Phys. 38 (1999) 5612.

[2] R. Liedtke, S. Hoffmann, R. Waser, J. Am. Ceram. Soc. 83 (2000) 436.

[3] V. K. Varadan, K. A. Jose, V. V. Varadan, R. Hughes, Microwave J. 2 (1995) 244.

[4] F. De Flaviis, IEEE Trans. Microwave Theory Tech. 45 (1997) 963.

[5] R. W. Babbitt, T. E. Koscica, Microwave J. 1 (1992) 63. [6] R. S. Liu, Y. C. Cheng, J. M. Chen, R. G. Liu, J. L. Wang, J. C. Tsai, M. Y. Hsu, Mater. Lett. 37 (1998) 285.

[7] S. Koerfer, R. A. De Souza, H. I. Yoo, M. Martin, Solid State Sci. 10 (2008) 725.

[8] Y. Syamaprasad, R. K. Galgali, B. C. Mohanty, Mater. Lett. 7 (1988) 197.

[9] L. Zhou, Z. Jiang, S. Zhang, J. Am. Ceram. Soc. 74 (1991) 2925.

[10] J. W. Liou, B. S. Chiou, Mater. Chem. Phys. 51 (1997) 59.

[11] L. Wu, Y. C. Chen, Y. P. Chou, Y. T. Tsai, S. Y. Chu, Jap. J. Appl. Phys. 38 (1999) 5612. 
[12] S. B. Herner, F. A. Selmi, V. V. Varadan, V. K. Varadan, Mater. Lett. 15 (1993) 317.

[13] W. Heywang, J. Mater. Sci. 6 (1971) 1214.

[14] N. H. Chan, R. K. Sharma, D. M. Smyth, J. Am. Ceram.
Soc. 65 (1982) 165.

[15] A. Yamaji, Y. Enomoto, K. Kinoshito, T. Murakami, J. Am. Ceram. Soc. 60 (1977) 97.

[16] T. Ashida, H. Toyoda, Jap. J. Appl. Phys. 5 (1966) 269. (Rec. 18/04/2011, Ac. 23/08/2011) 